\title{
CANDIDA ISOLATES IN TERTIARY HOSPITALS IN NORTHEASTERN BRAZIL
}

\author{
Sylvia Lemos Hinrichsen ${ }^{1 *}$; Érica Falcão ${ }^{2}$; Tatiana Aguiar Santos Vilella ${ }^{1}$; Leandro Rêgo ${ }^{3}$; Conceição Lira ${ }^{1}$; \\ Luciano Almeida²; Mízia Martins²; Carmem Araújo²; Marcelo Duarte²; Geraldo Lopes²
}

\author{
${ }^{1}$ Núcleo de Ensino, Pesquisa e Assistência em Infectologia, Universidade Federal de Pernambuco, \\ Recife, PE, Brasil; ${ }^{2}$ Cerpe Diagnósticos, Recife, PE, Brasil; ${ }^{3}$ Departamento de Estatística, Universidade Federal \\ de Pernambuco, Recife, PE, Brasil.
}

Submitted: March 27, 2008; Returned to authors for corrections: July 01, 2008; Approved: February 25, 2009.

\begin{abstract}
Candida is an opportunistic pathogen that affects high-risk patients who are either immunocompromised or critically ill and is associated with almost $80 \%$ of all nosocomial fungal infections, representing the major cause of fungemia with high mortality rates (40\%). Candida albicans is the main cause of candidemia and among the non-albicans species $C$. parapsilosis, $C$. glabrata and $C$. tropicalis are the most frequent agents. The aim of this study was to evaluate the distribution of Candida species in two tertiary hospitals in Recife, Northeastern Brazil. It began by surveying all positive Candida cultures processed by the microbiology laboratory from September 2003 to September 2006. The cultures, originated from various types of biological material (blood, urine, tracheal, catheter and others), were processed by Vitec ${ }^{\circledast}$ system (Biomerieux SA, France). A total of 1.279 (hospital A: 837; hospital B: 442) sample isolates were positive for Candida. The most frequent species in both hospitals were: C. albicans (367), C. tropicalis (363), C. parapsilosis (147), C. glabrata (81), C. krusei (30) and C. guillermondii (14). The isolates were obtained from 746 hospitalized patients. A total of 221 positive hemocultures were detected in 166 different patients in both hospitals, and $113(68.1 \%)$ of these patients with positive hemocultures presented Candida in other body sites. This study shows that Candida non-albicans was the main isolated agent and evidences the importante of $C$. tropicalis in nosocomial fungal infections.
\end{abstract}

Key words: Candida, candidemia, candida isolates.

Candida is an opportunistic pathogen that affects highrisk patients who are either immunocompromised or critically ill $(4,6,14,15)$.

Throughout the 1990s, the incidence of invasive fungal infections such candidiasis increased significantly worldwide, a concern because invasive fungal infections which are also difficult to diagnose, prevent, and treat $(7,14,15,17)$.

Candida is associated with almost $80 \%$ of all nosocomial fungal infections, representing the major cause of fungemia with high mortality rates $(40 \%)(4,6,8,14)$.

Candida albicans is the main cause of candidemia and among the non-albicans species $C$. parapsilosis, $C$. glabrata and $C$. tropicalis are the most frequent agents $(4,6,7,14,18)$.
Studies have demonstrated direct association between the number of body sities colonized and the incidence of candidiasis. Cultures are positive in only $50 \%$ of patients with invasive candidiasis, and diagnosis is confirmed ant mortens in only 15 to $40 \%$ of cases $(4,6,7,14,15,18,19,23)$.

The aim of this study is to evaluate the distribution of Candida species in tertiary hospitals in Northeastern Brazil.

This observational prospective study was performed at two tertiary private hospitals (hospital A: 217 beds; hospital B: 54 beds) in Recife, Pernambuco state, northeastern, Brazil. It began by surveying all positive Candida cultures processed by the microbiology laboratory from September 2003 to September 2006. A database was created with the following

*Corresponding Author. Mailing address: Rua Jornalista Guerra de Holanda, 158/2601. CEP 52061-010. Casa Forte, Recife, PE, Brasil.; Phone/Fax: 81 3268-9905. E-mail: sylviahinrichsen@ hotmail.com 
variables: age, gender, types of biological material, including urine, blood and other body sites and Candida species distribution.

During this period, all cultures originated from various types of biological material (blood, urine, tracheal, catheter and others) were processed by Vitec ${ }^{\circledR}$ system (Biomerrieux SA, France). Cultures were processed in accordance with NCCLS- National Committee for Clinical Laboratory Standards (14).

The statistical analysis was performed with the Epi-Info6.04 software through descriptive analysis for relative frequency and prevalence.

The study protocol was approved by the Institutional Ethics Committee ( $\mathrm{N}^{\circ}$ 1263/2003) and the resources for the development of the project were obtained from Cerpe Diagnosticos.

During the period of study, a total of 1.279 sample isolates were positive to Candida in both hospitals (Hospital A: $\mathrm{n}=837$; Hospital B: $n=442$ ) and the isolates were obtained from different body sites from 746 hospitalized patients (Hospital A: $n=496$; Hospital B: $n=250$ ) (Tables 1 and 2). The age of patients ranged from zero to 101 years with mean of 61.5 years (Median $=69$ years), and $55.1 \%$ were female and $44,9 \%$, male.

The most frequent species in both hospitals were: $C$. albicans $\mathrm{n}=367 ;$ C. tropicalis $\mathrm{n}=363 ;$ C. parapsilosis $\mathrm{n}=147$; C. glabrata $\mathrm{n}=81 ; C$. krusei $\mathrm{n}=30 ; C$. guillermondii $\mathrm{n}=14$ (Tables 1 and 2).

A total of 221 positive hemocultures were detected in 166 different patients in both hospitals. 113 (68.1\%) of these patients with positive hemocultures presented Candida in other body sites (Tables 1 and 2).

Brazilian reports (in public tertiary hospitals at southeastern) have revealed that $C$. albicans is the main agent of candidemia (20-50\%), followed by C. parapsilosis (17-35\%), C. tropicalis (12-27\%), and C. guilliermondii $(2-10 \%)(2,9)$.
The appearance of non-albicans isolates among patients admitted to tertiary care hospitals have been reported by different centers, including medical institutions from Brazil $(1,4,8,14,18,20)$.

In a candidemia study in a reference public tertiary hospital in Fortaleza, Ceará (Northeast Brazil) non-albicans species of Candida, were responsible for a total of $72 \%$ of fungemia cases. C. parapsilois $(\mathrm{n}=18)$ was the most isolated agent, followed by $C$. albicans $(\mathrm{n}=14), C$. tropicalis $(\mathrm{n}=8), C$. guillermonddii $(\mathrm{n}=6)$, C. glabrata $(\mathrm{n}=2)$ and Candida spp. $(\mathrm{n}=2)(14)$. In our study $C$. parapsilosis and $C$. tropicalis were the most frequent agents isolated in blood $(\mathrm{n}=148 ; 67,0 \%)$.

The increased use of invasive medical procedures as well as the prophylactic and empirical use of antifungal drugs, especially those of azolic derivation, has been blamed for the emergence of the non-albicans species of Candida $(10,12,19)$.

C. parapsilosis is widely recognized as a cause of fungemia among hospitalized patients $(4,14)$. C. parapsilosis is part of the endogenous microbiota of human beings and is a commensal organism, which penetrates the blood by rupting the sikin. The yeast is capable of forming biofilm in gucosilated solutions and adhering to plastic materials, such as catheters used for parenteral nutrition. Over the last few years, outbreaks and clusters of cross-transmission, total parenteral nutrition solutions, intravascular devices, and medications have been related to $C$. parapsilosis fungemia $(5,10,21)$. In addition, $C$. parapsilosis is an important pathogen of onychomycosis in fingernails $(3,11)$.

C. tropicalis presents as an important cause of fungemia in oncological and nononcological patients with diabetes, central venous catheters taking broad-spectrum antibiotics. The risk factors and presentation of $C$. tropicalis fungemia in comparison to that of $C$. albicans have been incompletely characterized $(3,17,19)$.

Table 1. Identification and sources of all 837 Candida spp. isolates, between September, 2003 and September, 2006 in the Hospital A* in Recife, PE, Brazil.

\begin{tabular}{lcccccc}
\hline \multicolumn{1}{c}{ SPECIES } & (Number) & Blood & Urine & Tracheal & Catheter & Miscellaneous** \\
\hline C. albicans & $(253)$ & $18(7.1 \%)$ & $62(24.5 \%)$ & $105(41.5 \%)$ & $15(5.9 \%)$ & $53(20.9 \%)$ \\
C.tropicalis & $(228)$ & $30(13.2 \%)$ & $45(19.7 \%)$ & $89(39.0 \%)$ & $31(13.6)$ & $33(14.5 \%)$ \\
C. parapsilosis & $(96)$ & $42(43.8 \%)$ & $6(6.3 \%)$ & $5(5.2 \%)$ & $31(32.3 \%)$ & $12(12.5 \%)$ \\
C. glabrata & $(59)$ & $9(15.3 \%)$ & $31(52.5 \%)$ & $8(13.6 \%)$ & $1(1.7 \%)$ & $10(16.9 \%)$ \\
C. guilliermondii & $(7)$ & $4(57.1 \%)$ & $0(0 \%)$ & $2(28.6 \%)$ & $0(0 \%)$ & $1(14.3 \%)$ \\
C. krusei & $(18)$ & $3(16.7 \%)$ & $2(11.1 \%)$ & $2(11.1 \%)$ & $4(22.2 \%)$ & $7(38.9 \%)$ \\
C. lusitaniae & $(6)$ & $0(0 \%)$ & $2(33.3 \%)$ & $4(66.7 \%)$ & $0(0 \%)$ & $0(0 \%)$ \\
C. famata & $(4)$ & $0(0 \%)$ & $0(0 \%)$ & $3(75.0 \%)$ & $1(25.0 \%)$ & $0(0 \%)$ \\
Candida spp. & $(166)$ & $3(1.8 \%)$ & $41(24.7 \%)$ & $23(13.9 \%)$ & $7(4.2 \%)$ & $92(55.4 \%)$ \\
\hline Total & 837 & $109(13.0 \%)$ & $189(22.6 \%)$ & $241(28.8 \%)$ & $90(10.8 \%)$ & $208(24.9 \%)$ \\
\hline
\end{tabular}

(*) Hospital A: 217 beds (**)Miscellaneous: wound material and others. 
Table 2. Identification and sources of all 442 Candida spp. isolates, between September, 2003 and September, 2006 in the Hospital B in Recife, PE, Brazil.

\begin{tabular}{lcccccc}
\hline \multicolumn{1}{c}{ SPECIES } & (Number) & Blood & Urine & Tracheal & Catheter & Miscellaneous** \\
\hline C. albicans & $(114)$ & $23(20.2 \%)$ & $27(23.7 \%)$ & $18(15.8 \%)$ & $6(5.3 \%)$ & $40(35.1 \%)$ \\
C.tropicalis & $(135)$ & $44(32.6)$ & $19(14.1 \%)$ & $29(21.5 \%)$ & $13(9.6 \%)$ & $30(22.2 \%)$ \\
C.parapsilosis & $(51)$ & $32(62.7 \%)$ & $3(5.9 \%)$ & $4(7.8 \%)$ & $7(13.7 \%)$ & $5(9.8 \%)$ \\
C.glabrata & $(22)$ & $2(9.1 \%)$ & $12(54.5 \%)$ & $4(18.2 \%)$ & $0(0 \%)$ & $4(18.2 \%)$ \\
C.guillermondi & $(7)$ & $3(42.9 \%)$ & $0(0 \%)$ & $1(14.3 \%)$ & $1(14.3 \%)$ & $2(28.6 \%)$ \\
C. krusei & $(12)$ & $5(41.7 \%)$ & $1(8.3 \%)$ & $3(25.0 \%)$ & $1(8.3 \%)$ & $2(16.7 \%)$ \\
C. lusitaniae & $(2)$ & $1(50.0 \%)$ & $0(0 \%)$ & $1(50.0 \%)$ & $0(0 \%)$ & $0(0 \%)$ \\
C. famata & $(3)$ & $1(33.3 \%)$ & $0(0 \%)$ & $1(33.3 \%)$ & $1(33.3 \%)$ & $0(0 \%)$ \\
Candida spp. & $(96)$ & $1(1.0 \%)$ & $25(26.0 \%)$ & $24(25.0 \%)$ & $6(6.3 \%)$ & $40(41.7 \%)$ \\
\hline Total & 442 & $112(25.3 \%)$ & $87(19.7 \%)$ & $85(19.2 \%)$ & $35(7.9 \%)$ & $123(27.8 \%)$ \\
\hline
\end{tabular}

(*) Hospital B: 54 beds (**)Miscellaneous: wound material and others.

Most infections appear to originate from the patients' alimentary tract microflora (22). The higher proportion of $C$. tropicalis in adult patients and older children hospitalized in oncology-hematology units might be partially explained by the prophylactic or empirical use of antifungal drugs (19). However, other differences, such as host defense deficiency and mucosal integrity, may be related to this discrepancy.

C. tropicalis appears to be more virulent than $C$. albicans in patients with hematological malignancies, and disseminated infection is associated with high mortality rates $(3,11,12)$. Among adults with or without cancer, systemic infections due to $C$. tropicalis have been associated with higher rates of mortality and dissemination than infection due to $C$. parapsilosis $(3,4,12)$.

Contrary to the United States and Europe where C. glabrata is the second or third most commonly species of Candida isolated from patients with invasive infections (20), C. glabrata and C. krusei isolates together represented only $8,8 \%$ of all yeast isolates in our study in Northeastern Brazil. In agreement with data reported by other investigators in Southeastern, Brazil who found $9,0 \%$, but higher than in other study in Northeastern, $\operatorname{Brazil}(5,0 \%)(2,9)$.

Concluding, our study confirmed data from previous studies that demonstrated high prevalence of candidemia in Brazil caused by species other than $C$. albicans, and shows that Candida non-albicans was the main isolated agent and evidences the importante of C. tropicalis and also, C. parapsilosis, in nosocomial fungal infections.

\section{ACKNOWLEDGEMENTS}

This study was supported by CNPq (Conselho Nacional de Desenvolvimento Científico e Tecnológico).

\section{RESUMO \\ Isolados de Candida em hospital terciário no nordeste do Brasil}

Candida é um patógeno oportunista que afeta pacientes de alto risco que estão também imunocomprometidos ou criticamente doentes, estando associada a quase $80 \%$ de todos os casos de infecções fúngicas nosocomiais, representando a maior causa de fungemia com alta taxa de mortalidade (40\%). Candida albicans é a principal causa de candidemia e dentre as espécies não-albicans a $C$. parapsilosis, $C$. glabrata e $C$. tropicalis são os agentes mais frequentes. O objetivo deste estudo foi avaliar a distribuição das espécies de Candida em dois hospitais terciários no Recife, nordeste do Brasil. Foi realizado um levantamento de todas as culturas positivas para Candida processadas pelo laboratório de microbiologia de Setembro de 2003 a Setembro de 2006. Todas as culturas originadas de vários tipos de material biológico (sangue, urina, traquéia, catéter e outros) foram processadas pelo sistema Vitec ${ }^{\circledast}$ (Biomerrieux SA, France). Um total de 1.279 amostras (hospital A:837; hospital B: 442) foram positivas para Candida. As espécies mais frequentes em ambos os hospitais foram: C.albicans (367), C. tropicalis (363), C. parapsilosis (147), C. glabrata (81), C. krusei (30) e C. guillermondii (14). Os isolados foram obtidos de 746 pacientes hospitalizados. Um total de 221 hemoculturas positivas foram detectadas em 166 diferentes pacientes em ambos os hospitais, e $113(68,1 \%)$ destes pacientes com hemoculturas positivas apresentavam Candida em outros locais do corpo. Este estudo mostrou que Candida não-albicans foi o principal agente isolado e prova a importância da $C$. tropicalis em infecções fúngicas nosocomiais.

Palavras-chave: Candida, candidemia, isolados de Candida 


\section{REFERENCES}

1. Abi-Said; Anaissie, E.; Uzyn, O. (1997). The epidemiology of hematogeneous candidiasis caused by different Candida species. Clin. Infec. Dis., 24: 1122-28.

2. Antunes, A.G.V.; Pasqualatto, A.C.; Diaz, M.C.; d'Azevedo, P.A; Severo, L.C. (2004). Candidemia em hospital terciário brasileiro: distribuição das espécies e padrões de susceptibilidade aos antifúngicos. Rev. Inst. Med. Trop. S. Paulo., 46(5): 239-241.

3. Brilhante, R.S.; Cordeiro, R.A.; Medrano, D.J. (2005) Onycchomicosis in Ceara (Northeast Brazil): epidemiological and laboratory aspects. Mem Inst Oswaldo Cruz, 100: 131-135.

4. Brito, L.R; Guimarães, T.; Nucci, M.; Rosas, R.C.; Almeida, L.P.; Matta, D.A.; Colombo, A.L. (2006). Clinical and microbiological aspects of candidemia due to $C$. parapsilosis in Brazilian tertiary care hospitals. Medical Mycology, 44: 261-66.

5. Clark, T.A.; Slavinski, S.A.; Morgan, J.; Lott, T.; Arthington-Skaggs, B.A.; Brandt, M.E.; Webb, R.M.; Currier, M.; Flowers, R.H.; Fridkin, S.K.; Hajjeh, R.A. (2004). Epidemiologic and molecular characterization of an outbreak of Candida parapsilosis bloodstream infections in a community hospital. J. Clin. Microbiol., 42: 44684472.

6. Colombo, A.L.; Nucci, M.; Parck, B.J. (2006). Epidemiology of candidemia in Brazil: a nationwide sentinel surveillance of candidemia in eleven medical centers. J. Clin. Microbiol., 44(8): 2816-23.

7. Colombo, A. (2000). Epidemiology and treatment of hematogenous candidiasis: a Brazilian prospective. Braz. J. Infect. Dis., 4(3): 113-18.

8. Colombo, A.L.; Nucci, M.; Salomão, R. (1999). High rate of non albicans in Brazilian tertiary care hospitals. Diagn. Microbiol. Infect. Dis., 34: 281-86.

9. Colombo, A.; Matta, D.; Almeida, L.P.; Rosas, R. (2002). Fluconazol susceptibility of Brazilian Candida Isolates Assessed by a Disk diffusion Method. BJID, 6(3): 118-23.

10. Durán, E.; Ramirez de Ocáriz, I.; Ventura, P.; Rubio, C. (2005). Candidemia: Candida parapsilosis in a neonatology unit. Rev. Iberoamer. Micol., 22: 64
11. Gautret, P.; Rodier, M.H.; Kaufmann-Lacroix, C.; Jacquemin, J.L. (2000). Case report and review. Onychomycosis due to Candida parapsilosis. Mycosis, 43: 433-435.

12. Goldani, L.Z.; Mario, P.S. (2003). Candida tropicalis fungemia in a tertiary care hospital. J. Infect., 46: 155-160.

13. Kontoyiannis, D.P.; Vaziri, I.; Hanna, H.; Thornby, U.; Boktour, M.; Hachem, R.; Bodey, G.P.; Raad, I.I. (2000). Risk Factors for Candida tropicalis Fungemia in Patients with Cancer. Abstr Intersci Conf Antimicrob Agents Chemother, 17-20; 40: 360.

14. Medrano, D.J.A.; Brillhante, R.S.N.; Cordeiro, R.A. (2006). Candidemia in a Brazilian hospital: the importance of Candida parapsilosis. Rev. Inst. Med. Trop. S. Paulo., 48(1): 17-20.

15. Morgan, J. (2005). Global trends in candidemia: review of reports from 1995-2005. Clin. Infect. Dis., 7: 429-439.

16. National Committee for Clinical Laboratory Standards (1997). Reference method for broth dilution antifungal susceptibility testing of yeasts. Approved standard NCCLS document M27-A. National Committee for Clinical Laboratory Standards, Wayne, Pa.

17. Nucci, M.; Colombo, A.L. (2002). Risk factors of breaktrough candidemia. Europ. J. Clin. Microbiol. Infect. Dis., 21: 209-11.

18. Nucci, M.; Silveira, M.I.; Spector, N. (1998). Fungemia in cancer patients in Brazil: predomine of non-albicans species. Mycopatologia., 141: 65-8.

19. Nucci, M.; Silveira, M.I.; Spector, N. (1998). Risk factores for death among cancer patients with fungemia. Clin. Infect. Dis., 27: 108-11.

20. Pfaller, M.A.; Jones, R.N.; Doern, G.V.; Sader, H.S.; Hollis, R.J.; Messer, S.A. (2000). Bloodstream infections due to Candida species: SENTRY antimicrobial surveillance program in North America and Latin America, 1997-1998. Antimicrob. Agents. Chemother, 44(3): 747-51.

21. Silva, C.L.P.; Santos, R.M.R.; Colombo, A.L. (2001). Cluster of Candida parapsilosis primary bloodstream infection in neonatal intensive care unit. BJID, 5(1): 32-36.

22. Walsh, T.J.; Merz, W.G. (1986). Pathologic features in the human alimentary tract associated with invasiveness of Candida tropicalis. Am. J. Clin. Pathol., 85: 498-502.

23. Wey, S.B.; Mori, M.; Pfaller, M.A.; Woolson, R.F.; Wenzel, R.P. (1998). Hospital acquired candidemia. The attibutable mortality and excess length of stay. Arch. Intern. Med., 148: 2642-45. 